\title{
Virulence of Escherichia coli Strains with R-plasmid Mediated Penicillin Resistance in Mice Infections
}

\author{
Yoshiki OBANA and Takeshi NISHINO \\ Department of Microbiology, Kyoto Pharmaceutical University \\ (Received: February 22, 1991) \\ (Accepted: April 8, 1991)
}

Key words: R-plasmid, penicillinase, virulence, conjugation

\begin{abstract}
Penicillinase I-, II- and III-producing R-plasmid of Escherichia coli were transferred to Escherichia coli $177, \mathrm{KC}-14$, and 444 . These strains are highly virulent in mice. This study was conducted to investigate the influence of conjugative R-plasmid on the virulence of its host strains. Escherichia coli 177 after penicillinase I- or III-producing R-plasmids transfer retained parental levels of virulence. On the other hand, penicillinase II-producing transconjugants showed reduced virulence in mice. The virulence of its revertants, in which R-plasmid was eliminated by heat, were equivalent to that of the host strain. It is suggested that the decrease in the virulence of transconjugants was not due to transferred R-plasmid. The reduced virulence of the these transconjugants may be due to alterations in their components such as the lipopolysaccharides in the cell envelope.
\end{abstract}

\section{Introduction}

With increasing use of penicillins such as amoxicillin and piperacillin, resistant strains of several Gram-negative bacteria are isolated more frequently. These strains exhibit a high level of resistance to almost all penicillins. Resistance is restricted to penicillins and based on the production of large amount of the plasmid mediated penicillinase. However, these antibiotic-resistant strains are sometimes, though not always, less virulent than antibiotic-susceptible strains in mice infections ${ }^{1,2,3)}$. The reduced virulence, as pointed out by Cavalieri et al. ${ }^{4)}$ could have several causes: reduced invasiveness, increase in adherence to epithelial cells or a low production level of relevant enzymes. We have previously shown methicillinresistant Staphylococcus aureus to generally be of low virulence, based on virulence studies of experimentally-induced sepsis and respiratory tract infections in mice ${ }^{5}$. However, few experiments have been reported on the influence of conjugative R-plasmid on the virulence of bacteria.

The aim of this study was to investigate the influence of conjugative R-plasmids on the virulence of Escherichia coli in mice.

\section{Materials and Methods}

\section{Bacterial strains}

Penicillin-resistant Escherichia coli 21 (penicillinase I-producing), 195 (penicillinase II-producing) and 33 (penicillinase III-producing) were used. Escherichia coli ST0198, 177, KC-14, and 444, susceptible to penicillin, were used as the recipients in this study.

別刷請求先：（テ607）京都市山科区御陵中内町 5 番地 京都薬科大学微生物学教室 尾花 芳樹 


\section{Antibiotics}

Ampicillin, carbenicillin, piperacillin, cefotiam, cefuroxime, gentamicin, minocycline and nalidixic acid were used. Solutions of the antimicrobial agents were freshly prepared each day.

\section{Transfer studies}

R-plasmid transfer consists of two steps. In the first step, Escherichia coli ST0198, a non-lactosefermenting strain, was added to Escherichia coli 21,195 and 33, all lactose-fermenting strains, at a 10:1 ratio (10 Escherichia coli ST0198 and $10^{7}$ of Escherichia coli 21,195 or 33). The mating mixture was incubated at $37^{\circ} \mathrm{C}$ for $60 \mathrm{~min}$. Bacteria were cultured on BTB lactose agar plates containing $100 \mu \mathrm{g} / \mathrm{ml}$ of ampicillin. Transconjugant colonies from each mixture (designated $21 \mathrm{R}, 195 \mathrm{R}$ and $33 \mathrm{R}$, respectively) were subcultured on similar selective plates. These were confirmed to be penicillinase (PCase) producers and identified with Minitex ${ }^{\circledR}$ systems. In the second step, Escherichia coli 177, a lactose-fermenting strain highly virulent in mice, was added to $21 \mathrm{R}, 195 \mathrm{R}$ or $33 \mathrm{R}$, respectively at a $10: 1$ ratio $\left(10^{8}\right.$ Escherichia coli 177 and $10^{7}$ of $21 \mathrm{R}, 195 \mathrm{R}$ or $33 \mathrm{R}$ ). Conjugation experiments were carried out for $60 \mathrm{~min}$ at $37^{\circ} \mathrm{C}$. All lactosefermenting transconjugant colonies (designated 177/21R, 177/195R and 177/33R, respectively) were selected on BTB lactose agar plates containing $100 \mu \mathrm{g} / \mathrm{ml}$ of ampicillin and identified with Minitex ${ }^{\circledR}$ systems. The stability of the plasmids in the transconjugants was assessed by daily subculture on nonselective media. After ten subcultures, individual colonies were screened for PCase production using the substrate nitrocefin. In addition, PCase II-producing R-plasmid from strain 195R was similarily transferred to Escherichia coli $\mathrm{KC}-14$ and 444 . These are highly virulent in mice and also ferment lactose. The five transconjugants were designated KC-14/195R and 444/195R, respectively.

\section{Susceptibility to antibiotics}

The minimum inhibitory concentrations (MICs) were determined by agar dilution using sensitivity test agar and an inoculum of $10^{6} \mathrm{cfu}$.

\section{Determination of virulence}

Virulence was tested in ddY-male mice that weighed between 18 and $20 \mathrm{~g}$. Ten-fold serial dilutions of overnight cultures were injected intraperitoneally as suspensions in $3 \%$ hog gastric mucin. Eight mice were used for each dilution level. The number of viable bacteria injected was determined by plating. The $50 \%$ lethal dose $\left(\mathrm{LD}_{50}\right)$ was defined as the viable count resulting in death of $50 \%$ of the animals due to bacteremia. The $L D_{50}$ was calculated by the probit method from the survival rates on day 5 after infection. Evaluation of bacterial clearance from the mouse blood

Test bacteria were diluted in nutrient broth to a concentration of approximately $1 \times 10^{7} \mathrm{cfu} / \mathrm{ml}$ and 0.2 $\mathrm{ml}$ volumes were injected into the tail vein of mice. At selected intervals, blood samples were drawn from the retroorbital plexus. Viable cell counts were determined by plating on to BTB lactose agar plates and incubating overnight at $37^{\circ} \mathrm{C}$.

\section{Sensitivity to lysozyme}

Logarithmic-phase bacteria were spun down and resuspended in Tris buffer ( $\mathrm{pH} 7.0$ ). Sufficient amounts of Tris buffer, disodium EDTA and egg-white lysozyme were then added to give final concentrations $25 \mathrm{mM}, 0.5 \mathrm{mM}$ and $30 \mu \mathrm{g} / \mathrm{ml}$, respectively. Tubes were incubated at $37^{\circ} \mathrm{C}$ and read at the specified intervals on the spectrophotometer.

\section{Toxicity of lipopolysaccharides}

The lipopolysaccharides (LPS) samples were prepared from cells grown in nutrient broth to the late-logarithmic phase as previously described by O'Neill et $a^{6}{ }^{6}$. The toxicity of the LPS was studied in mice by observing the five-day survival after intravenous injection of the LPS dissolved in physiological saline solution. 


\section{Results}

\section{Susceptibility to antibiotics}

Table 1 shows that all transconjugants exhibited a high level of resistance to ampicillin, carbenicillin and piperacillin. These transconjugants appeared to produce large quantities of stable penicillinase (PCase), as could be deduced from the rapid color change when single colonies were checked with a drop of nitrocefin. No differences in biochemical reaction, colony form or growth in nutrient broth and fresh mouse serum were found between the parental strain and the transconjugations (data not shown).

\section{Virulence}

The transconjugants $177 / 195 \mathrm{R}, \mathrm{KC}-14 / 195 \mathrm{R}$ and $444 / 195 \mathrm{R}$ were more than 500 - to 10,000 -fold less virulent than the corresponding parental strains. A series of $177 / 195 \mathrm{R}$ and KC-14/195R, interestingly, showed a distinctly reduced virulence in mice. The difference in bacterial virulence between the parental strains and their transconjugants was statistically significant in all cases (Table 2). In addition, 177/195R was subcultured in nutrient broth at $45^{\circ} \mathrm{C}$ for $18 \mathrm{~h}$, and five strains with reduced resistance (lacking R-plasmid; designated $177 / 195 \mathrm{R} / \mathrm{rr}$ ) were obtained. No differences in virulence were found between

Table 1 Sensitivity of wild-type strains of Escherichia coli and transconjugants carrying various R-plasmids to eight antimicrobial agents

\begin{tabular}{lccccccccc}
\hline \multirow{2}{*}{ Strain } & \multirow{2}{*}{$\begin{array}{c}\text { No. of } \\
\text { strains }\end{array}$} & \multicolumn{7}{c}{ Minimum inhibitory concentration $(\mu \mathrm{g} / \mathrm{ml})$ at $10^{6}$ cfu } \\
\cline { 3 - 10 } & & ABPC & CBPC & PIPC & CTM & CXM & GM & MINO & NA \\
\hline Escherichia coli 177 & 1 & 1.56 & 3.13 & 0.78 & 0.05 & 0.39 & 0.39 & 3.13 & 0.78 \\
$177 / 21 \mathrm{R}$ & 3 & $>800$ & $>800$ & $400 \sim>400$ & $0.1 \sim 0.2$ & $0.78 \sim 1.56$ & 0.39 & 3.13 & 0.78 \\
$177 / 195 \mathrm{R}$ & 5 & $400 \sim 800$ & $400 \sim 800$ & $50 \sim 200$ & $0.1 \sim 0.2$ & $0.78 \sim 3.13$ & 0.39 & 12.5 & 3.13 \\
$177 / 33 \mathrm{R}$ & 2 & $>800$ & $800 \sim>800$ & ND* & 0.1 & 0.39 & 0.39 & $3.13 \sim 6.25$ & 0.78 \\
\hline Escherichia coli KC-14 & 1 & 6.25 & 6.25 & ND & ND & ND & ND & ND & 0.78 \\
KC-14/195R & 5 & $>400$ & $>400$ & ND & ND & ND & ND & ND & 3.13 \\
\hline Escherichia coli 444 & 1 & 3.13 & 1.56 & ND & ND & ND & ND & ND & 0.78 \\
444/195R & 5 & $>400$ & $>400$ & ND & ND & ND & ND & ND & 3.13 \\
\hline
\end{tabular}

Abbreviations: ABPC, ampicillin; CBPC, carbenicillin; PIPC, piperacillin ; CTM, cefotiam ; CXM, cefuroxime ; GM, gentamicin; MINO, minocycline; NA, nalidixic acid.

${ }^{*}$ Not done

Table 2 The $50 \%$ lethal dose values of wild-type strains of Escherichia coli and transconjugants carrying various R-plasmids in mice

\begin{tabular}{|c|c|c|c|c|}
\hline \multirow{2}{*}{ Strain } & \multirow{2}{*}{ Penicillinase } & \multirow{2}{*}{$\begin{array}{l}\text { No. of } \\
\text { strains }\end{array}$} & \multicolumn{2}{|c|}{$50 \%$ lethal dose (cells/mouse) } \\
\hline & & & Range & Mean \\
\hline Escherichia coli 177 & - & 1 & - & $4.0 \times 10^{2} 7$ \\
\hline $177 / 21 \mathrm{R}$ & $\mathrm{I}$ & 3 & $6.0 \times 10-4.0 \times 10^{3}$ & $6.0 \times 10^{2}$ \\
\hline $177 / 195 \mathrm{R}$ & II & 5 & $1.6 \times 10^{6}-5.0 \times 10^{6}$ & $3.2 \times 10^{6}$ \\
\hline $177 / 33 \mathrm{R}$ & III & 2 & $2.0 \times 10^{2}-4.5 \times 10^{2}$ & $3.2 \times 10^{2}$ \\
\hline Escherichia coli $\mathrm{KC}-14$ & - & 1 & - & $7.0 \times 10^{2}$ \\
\hline KC-14/195R & II & 5 & $1.8 \times 10^{6}-1.8 \times 10^{7}$ & $6.4 \times 10^{6 *}$ \\
\hline Escherichia coli 444 & - & 1 & - & $6.0 \times 10^{3}$ \\
\hline $444 / 195 R$ & II & 5 & $1.5 \times 10^{6}-4.5 \times 10^{6}$ & $2.8 \times 10^{6 *}$ \\
\hline
\end{tabular}

Mice were inoculated intraperitoneally with bacterial suspensions in $3 \%$ gastric mucin ${ }^{*} \mathrm{p}<0.01$ 
$177 / 195 \mathrm{R}$ and a series of 177/195R/rr (Table 3). Escherichia coli 177 retained parental levels of virulence after PCase I- or III-producing R-plasmid transfer (Table 2).

\section{Clearance of the bacteria after intravenous injection}

To explore biological differences between Escherichia coli 177 and its transconjugant $177 / 195 \mathrm{R}$, we examined the clearance of these organisms from the bloodstream following intravenous injection in mice. More 177/195R was cleared from the circulation than Escherichia coli 177 (Fig. 1).

\section{Sensitivity to lysozyme}

Escherichia coli 177 was appreciably lysed after a $120 \mathrm{~min}$ incubation with the EDTA-lysozyme-Tris mixture described in the Materials and Methods section. Transconjugant 177/195R, however, underwent lysis. This was indicated by a gradual decrease in the spectrophotometric reading, and turbidity fell by $50 \%$ in $120 \mathrm{~min}$ (Fig. 2).

\section{Toxicity of lipopolysaccharides}

When mice were intravenously given with lipopolysaccharides obtained from Escherichia coli 177 and $177 / 195 \mathrm{R}$, the $50 \%$ lethal doses $\left(\mathrm{LD}_{50 \mathrm{~s}}\right)$ were $0.25 \mathrm{mg} / \mathrm{mouse}$ and $0.70 \mathrm{mg} / \mathrm{mouse}$, respectively, showing considerable difference between the two (Table 4).

Table 3 The 50\% lethal dose values of Escherichia coli 177/195R carrying R-plasmid and its cured strains Escherichia coli $177 / 195 \mathrm{R} / \mathrm{rr}$ in mice

\begin{tabular}{lcccc}
\hline \multirow{2}{*}{ Strain } & \multirow{2}{*}{ Penicillinase } & \multirow{2}{*}{$\begin{array}{c}\text { No. of } \\
\text { strains }\end{array}$} & & \multicolumn{2}{c}{$50 \%$ lethal dose (cells/mouse) } \\
\cline { 5 - 6 } & & & Range & Mean \\
\hline Escherichia coli 177 & II & 1 & - & $3.0 \times 10^{2}$ \\
$177 / 195 \mathrm{R}$ & - & 5 & $2.7 \times 10^{6}-6.0 \times 10^{6}$ & $4.5 \times 10^{6 *}$ \\
$177 / 195 \mathrm{R} / \mathrm{rr}$ & - & & &
\end{tabular}

Mice were inoculated intraperitoneally with bacterial suspensions in $3 \%$ gastric mucin ${ }^{*} \mathrm{p}<0.01$

Fig. 1 Clearance of Escherichia coli $177(\bullet)$ and its transconjugant $177 / 195 \mathrm{R}(\mathrm{O})$ carrying R-plasmid from blood of mice after intravenous inoculation. Five mice were used for each group in this experiment.

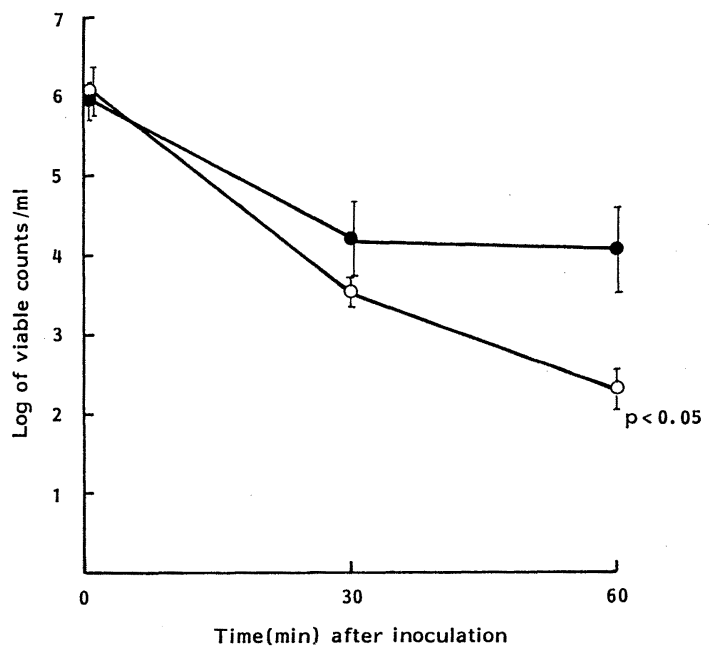

平成 3 年 9 月 20 日
Fig. 2 Sensitivity of Escherichia coli $177(\bullet)$ and its transconjugant $177 / 195 \mathrm{R}(\mathrm{O})$ carrying $\mathrm{R}$ plasmid to egg-white lysozyme.

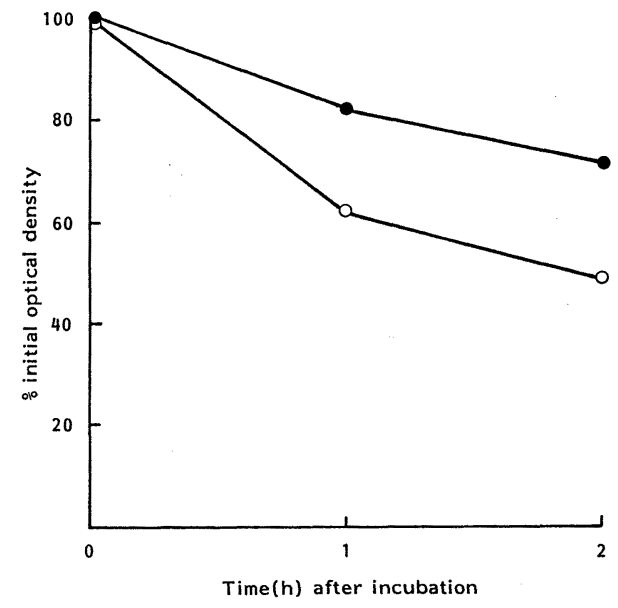


Table 4 Toxicity of lipopolysaccharide from Escherichia coli 177 and its transconjugant carrying R-plasmid

\begin{tabular}{lccc}
\hline $\begin{array}{c}\text { Lipopolysaccharide } \\
\left.\text { from }^{\mathrm{a}}\right)\end{array}$ & Penicillinase & $\begin{array}{c}\text { Yield } \\
(\mathrm{mg} / 100 \mathrm{mg} \text { dry wt. bacteria })\end{array}$ & 50\% lethal dose (mg/mouse $)^{\mathrm{b})}$ \\
\hline Escherichia coli 177 & - & 4.00 & 0.25 \\
177/195R & II & 2.83 & 0.70 \\
\hline
\end{tabular}

a) LPS samples were injected intravenously.

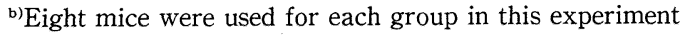

\section{Discussion}

One mode of antibiotic-resistance to penicillins in Gram-negative bacteria is usually mediated by R-plasmid transfer. All determinants of resistance were transfered by conjugation at a high frequency. Additionally, this resistance was quite stable. In general, however, the antibiotic-resistant bacteria, especially these possessing R-plasmid, are said to be less virulent than the antibiotic-sensitive bacteria when inoculated into mice because of theirs low growth-rate ${ }^{2,7)}$. In contrast, results of a recent study with Pseudomonas aeruginosa showed no decrease in virulence for several $\beta$-lactam-resistant mutants ${ }^{8)}$. Experiments were performed to study the influence of R-plasmids on virulence in mice. Escherichia coli 177 retained virulence similar to Escherichia coli 177 after transfer of penicillinase (PCase) I- or III-producing R-plasmids. Fifteen Escherichia coli strains were rendered resistant to ampicillin after R-plasmid transfer from Escherichia coli 195 possessing PCase II-producing plasmid. These strains were less virulent than the respective parental strains when injected into mice, as shown by the increased $50 \%$ lethal dose. Besides $\beta$-lactamase overproduction, these transconjugants show no alteration of morphology or growth-rate. The reduced virulence was maintained even when 177/195R lost its resistance to ampicillin after incubation at high temperatures in nutrient broth (Table 3 ). No correlation could be found between changes in virulence and those in possession of R-plasmid. Watanabe ${ }^{7)}$ using Salmonella typhimurium LT-2 into which R-factor of Shigella was transferred, reported that the reduced virulence of Salmonella typhimurium with R-factor was not due to the function of the R-factor, but the nature of the cell wall polysaccharide of the host bacteria. It may be that this cell wall composition also facilitates the transfer of R-factors. Moreover, Then et al. ${ }^{9)}$ have also reported similar results. The cell wall is the first structure in most bacteria to interact with the host. Therefore its chemical composition may be important in the relationship between bacteria and host. One of the strategies that Gram-negative bacteria employ to evade host defences appears to be related to the amount and chemical composition of the bacterial surface lipopolysaccharides (LPS). The possession of fully capped LPS (smooth LPS) is a well-known virulence factor in Gram-negative bacteria. Long O-polysaccharide chains on the LPS of enteric bacteria allow the organisms to survive in vivo. Presumably, these chains render them by their resistance to the potential bacteriolytic action of serum and to phagocytosis. Conversely, avirulent mutants possess shorter polysacchride side chains. Therefore, experiments using cell envelope, especially LPS, were performed. The transconjugant 177/195R was more susceptible to phagocytosis by macrophages and lysozyme than Escherichia coli 177 (Fig. 1 and 2). The LPS obtained from 177/195R was also less toxic than that obtained from Escherichia coli 177. Additionally, the yield of LPS from 177/195R was only $70 \%$ of that from Escherichia coli 177 . On the basis of these observations, it seemed possible that PCase II-producing R-plasmids were preferentially being introduced into transconjugants with minor LPS and reduced virulence. Nakano et al. ${ }^{10)}$ reported that Salmonella typhimurium mutants, with altered LPS, possess an increased capacity to receive R-plasmid. Medearis $e t$ al. ${ }^{11)}$ using two mutants of Escherichia coli which produce altered LPS, Jarolmen et al. ${ }^{12)}$ and Watanabe ${ }^{13)}$ obtained similar results. It is suggested that alterations in minor LPS may create conditions more favorable 
to the formation of mating pairs. Mutants of Salmonella typhimurium ${ }^{14)}$, Pseuodmonas aeruginosa ${ }^{15)}$ and Enterobacter cloacae ${ }^{9)}$ with increased susceptibility to hydrophobic agents, detergents and dyes have been described. Minor mutations in outer membrane proteins or LPS may produce these phenotypes, but in no case are the underlying mechanisms for resistance well understood. The 177/195R series, however, have shown decreased susceptibility to hydrophobic agents such as nalidixic acid and minocycline (Table 1), detergents, and dyes (data not shown). Moreover, 177/195R as compared with that of Escherichia coli 177 indicated the increased hydrophobicity (data not shown). In addition, the colonies of these transconjugants have smooth appearence. From these findings, the idea of a mutation in LPS is not supported. More subtle changes which have not yet been detected may be responsible for this phenomenon. Studies are now being conducted on the surface structures of these transconjugants. We are currently evaluating the increased susceptibility of transconjugants to host-defence mechanisms, such as phagocytosis. In addition, whether ability to receive PCase II-producing R-plasmid is directly related to the degree of alterations in minor LPS in this and other genera is also being considered. Antibiotic therapy should be carefully monitored when treating infections due to enteric bacteria carrying the R-plasmid.

\section{References}

1) Bryson, V. \& Demerec, M.: Bacterial resistance. Am. J. Med. 18: 723-737, 1955.

2) Watanabe, T., Sugawara, K. \& Watanabe, M.: Virulence of rifampicin-resistant mutants of bacteria. Jpn. J. Bacteriol. (in Japanese) 26: 192-199, 1971.

3) Suzuki, K., Nakamura, A., Tamaki, S. \& Ito, T.: Factors affecting virulence of drug-resistant bacteria. Chemotherapy (in Japanese) 26: 209-215, 1978.

4) Cavalieri, S.J., Bohach, G.A. \& Snyder, I.S.: Escherichia coli-hemolysin: characteristics and probable role in pathogenicity. Microbiol. Rev. 48: 326-343, 1984.

5) Obana, Y., Nishino, T. \& Tanino, T.: The virulence of methicillin-resistant Staphylococcus aureus in mice. J. Jpn. Assoc. Infect. Dis. (in Japanese) 60: 1133-1139, 1986.

6) O'Neill, G.J. \& Todd, J.P.: Extraction of nucleic acid-free lipopolysaccharides from gram-negative bacteria. Nature 190: 344-345, 1961.

7) Watanabe, M.: Effect of $R$ factors on the virulence of their host bacteria: Virulence for mice of Salmonella typhimurium LT-2 carrying various R factors from naturally occurring Shigella strains. Jpn. J. Bacteriol. (in

Japanese) 31: 397-407, 1976.
8) Bryan, L.E., Godfrey, A.J. \& Schollardt, T.: Virulence of Pseudomonas aeruginosa strains with mechanisms of microbial persistence for $\beta$-lactam and aminoglycoside antibiotics in a mouse infection model. Can. J. Microbiol. 31: 377-380, 1985.

9) Then, R.L. \& Angehrn, P.: Multiply resistant mutants of Enterobacter cloacae selected by $\beta$-lactam antibiotics. Antimicrob. Agents Chemother. 30: 684-688, 1986.

10) Nakano, M. \& Saito, K.: Chemical components in the cell wall of Salmonella typhimurium affecting its virulence and immunogenicity in mice. Nature 222: 1085-1086, 1969.

11) Medearis, D.N., Camitta, B.M. \& Heath, E.C.: Cell wall composition and virulence in Escherichia coli. J. Exp. Med. 128: 399-414, 1968.

12) Jarolmen, H. \& Kemp, G.: Association of increased recipient ability for $R$ factors and reduced virulence among variants of Salmonella choleraesuis var. kunzendorf. J. Bacteriol. 97: 962-963, 1969.

13) Watanabe, T., Arai, T. \& Hattori, T.: Effects of cell wall polysaccharide on the mating ability of Salmonella typhimurium. Nature 225: 70-71, 1970.

14) Sukupolvi, S., Vaara, M., Helander, J.M., Viljanen, P. \& Makela, P.H.: New Salmonella typhimurium mutants with altered outer membrane permeability. J. Bacteriol. 159: 704-712, 1984.

15) Fyfe, J.A.M. \& Govan, J.R.W.: Chromosomal loci associated with antibiotic hypersensitivity in pulmonary isolates of Pseudomonas aeruginosa. J. Gen. Microbiol. 130: 825-834, 1984. 
マウスに対するペニシリン耐性 R プラスミド保有大腸菌の菌力について

京都薬科大学微生物学教室

尾 花 芳 樹 西 野 武 志

(平成 3 年 2 月 22 日受付)

(平成 3 年 4 月 8 日受理)

\section{要旨}

Escherichia coli の保有する I，II 抢よびIII型ぺ ニシリナーゼ産生 R プラスミドをマウスに対し て強い菌力を示す Escherichia coli 177株, KC-14 株, および444株に接合伝達し, 菌力に及ぼす伝達 性 $\mathrm{R}$ プラスミドの影響について調べた．I拈よび III型ペニシリナーゼ産生 R プラスミドをEscherichia coli 177株に伝達したところ, 伝達前の菌力 とほぼ同等であった。一方，II型ペニシリナーゼ
産生の接合伝達株はマウスに対する菌力が低下し ていた. 高温培養により $\mathrm{R}$ プラスミドを脱落させ

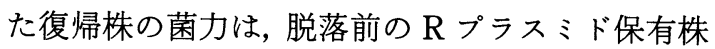
とほぼ同等であった。 これらの成績から, 接合伝 達株の菌力の低下は接合伝達された $\mathrm{R}$ プラス ドの影響によるものではないことが示唆され，こ れは細胞表層のリポ多糖体などの細胞構築の変化 によるものであると考ている. 